\title{
Orientasi Beragama dan Implikasinya pada Daya Berfikir Kritis Mahasiswa Universitas Negeri Jakarta
}

\author{
Sari Narulita \\ Universitas Negeri Jakarta \\ Sari-Narulita@unj.ac.id \\ Miftahul Jannah \\ STAI Nur El-Ghazy \\ Miftahul.jannah@neg.ac.id
}

\begin{abstract}
Many factors cause weak thinking power in religion; one of them is religious orientation. This article aims to map the religious orientation of UNJ students so that it can be understood the direction, its tendency and its implications on its critical power. The study used a descriptive analytical approach with the acquisition of data through observation, questionnaires, and interviews. The findings are prepared with data presentation to be analyzed and drawn conclusions, as well as inputs and suggestions that can be submitted. The results of the study show that in general, religious orientation does not correlate with critical power in religion. But specifically, it was found that intrinsic orientation has a strong enough correlation with students' thinking ability. To increase the level of intrinsic orientation can be done by following religious studies.
\end{abstract}

Keywords: Religious Orientation, Student, Critical thinking

\begin{abstract}
Abstrak
Lemahnya daya pikir dalam beragama disebabkan oleh banyak faktor, salah satunya di tenggarai oleh orientasi beragamanya. Artikel ini bertujuan untuk memetakan orientasi beragama mahasiswa UNJ, sehingga bisa dipahami arah, kecenderungannya dan implikasinya pada daya kritisnya. Penelitian menggunakan pendekatan deskriptif analitis dengan perolehan data melalui observasi, kuesioner dan wawancara. Temuan disusun dengan sajian data untuk dianalisis dan ditarik kesimpulan, serta masukan dan saran yang bisa diajukan. Hasil penelitian menunjukkan secara umum, orientasi beragama tidak berkorelasi dengan daya kritis dalam beragama. Namun secara spesifik ditemukan bahwa orientasi instrinsik memiliki korelasi yang cukup kuat terhadap daya pikir dalam beragama mahasiswa. Untuk meningkatkan tingkat orientasi instrinsik bisa dilakukan dengan mengikuti pengajian dan pengkajian agama.
\end{abstract}

Kata kunci: Orientasi Beragama, Mahasiswa, Daya Berfikir Kritis 


\section{A. Pendahuluan}

Ukuran kesuskesan dan keberhasilan dalam dunia akademik masih dipandangan dalam bentuk angka. Mahasiswa dikatakan sukses secara akademik ketika memiliki nilai yang tinggi. Sayangnya nilai yang tinggi tidak selamanya mampu menghantarkan kepada kesuksesan dan keberhasilan hidup apabila tidak diimbangi dengan daya berfikir kritis. Daya berfikir kritis dapat mendorong mahasiswa untuk memahami tema dan permasalahan berdasarkan yang ada pada buku ataupun perkuliahan semata lebih jauh dari itu mahasiswa dapat menganalogikan beragam permasalahan yang terdapat dalam kehidupan sehari-hari.

Mahasiswa sebagai sosok yang baru beranjak dewasa adalah mereka yang dianggap telah memasuki masa kognitif tingkat tinggi, diharapkan daya berfikir kritis dapat menguat dalam semua aspek. Namun fakta menunjukkan hal yang tidak koheren dengan usia mahasiswa dimana pelaku terror atasnama agama banyak dilakukan mereka yang memasuki usia ini. Sebagai contoh, pengantin bom bunuh diri di hotel JW Marriot dan Ritz Carlton di Jakarta tertanggal 17 Juli 2009 diidentifikasi sebagai Dani Dwi Permana (19 tahun) dan Nana Ikhwan (28). ${ }^{1}$ Idealnya, di usia mereka yang masuk pada usia kategori dewasa awal, kemampuan kognitifnya telah mencapai titik klimaknya ${ }^{2}$. Namun yang terjadi adalah keyakinan akan kebenaran apa yang dianutnya tanpa menggunakan nalar berfikir kritis seolah-olah membenarkan apa yang salah menurut logika. Hingga akhirnya membuat mereka pasrah menjadi pengantin bom bunuh diri sebagai sebuah kebenaran.

Lemahnya daya berfikir kritis, khususnya mengenai agama disebabkan oleh banyak factor diantaranya; kurangnya pemahaman agama, lingkungan yang tidak mendukung serta minimnya tingkat orientasi beragama seseorang. Yang dimaksud

\footnotetext{
${ }^{1}$ Lihat http://news.detik.com/berita/1179628/dani-dwi-permana-pelaku-bom-marriott-tinggal-dikahuripan-bogor,

http://tekno.kompas.com/read/2009/08/08/18180192/pelaku.bom.bunuh.diri.marriott.remaja.18.tahun dan banyak berita lainnya

${ }^{2}$ Dalam teori Piaget, anak di atas usia 11-15 tahun sudah melalui masa operasional formal, yakni masa dimana seseorang mampu menggunakan hasil operasional konkret dan membuat hipotesis tentang berbagai hubungan logis yang ada. Dengan demikian pemikiran remaja akan sangat logis, abstrak dan hipotekal. Selain itu, remaja pada operasional formal lebih memikirkan berbagai kemungkinan jawaban sebelum ia menjawab atau sebelum bertindak. Lihat ragam buku terkait Perkembangan Kognitif Piaget, seperti karya David Alkind dan John H Flavell, Studies in Cognitive development; essays in honor of Jean Piaget. New York: Oxford University Press, 1969
} 
orientasi beragama adalah pemaknaan agama dalam kehidupannya. Urgensi agama dalam hidup dan kehidupan seseorang membawanya kepada bagaimana pengimplementasiannya dalam kehidupan atau yang disebut juga cara beragama. Secara garis besar, agama seseorang berdasarkan tradisi. Hal ini diyakini sebagai ketersambungan keyakinan dengan nenek moyang, leluhur dan pendahulu sebelumnya. Seseorang yang beragama dengan tradisional umumnya sulit menerima pembaharuan dalam agama.

Disisi lain, masih banyak yang beragama dengan cara formal, yakni dimana agama sekedar label formalitas semata. Seseorang yang menganggap agama sebagai formalitas umumnya adalah mereka yang tidak memiliki rasa keberagamaan yang kuat, sehingga tidak sulit baginya mengubah cara dan keyakinan agamanya bila berpindah lingkungan. Beragama secara rasional, yakni beragama disertai nalar kritis dalam melaksanakan ritual keagamaan. Cara terakhir dalam beragama adalah beragama dengan akal dan hati, yakni mereka yang menghayati dan juga mendalami agama dengan sangat baik. Di tangan merekalah agama menjadi lebih sederhana dan mudah diimplementasikan.

Keberagamaan seseorang dipengaruhi oleh orientasi beragamanya. Sebagaimana yang Allport dan Ross dalam Wibisono bahwa orientasi beragama dibagi atas 2 (dua) hal, yakni orientasi instrinsik dan orientasi ekstrinsik ${ }^{3}$. Pemeluk dengan tipe orientasi instrinsik adalah yang beragama dengan penuh penghayatan. Agama merupakan kebutuhan spiritual yang difungsikan untuk mengatasi rasa egois, kepentingan pribadi dan juga pemenuhan pengembangan diri. Sedangkan mereka yang berorientasi ekstrinsik adalah mereka yang berupaya mendapatkan penghargaan secara sosial dengan agama yang dianutnya. Mereka menjadikan agama sebagai upaya memperbaiki status, menjadi orang terpandang bahkan menjadikannya sebagai alat untuk menjatuhkan orang lain.

Dimensi Ekstrinsik adalah suatu kecenderungan dimana agama digunakan untuk memperoleh keamanan, mengatasi kebingungan, status; Agama sesuai dengan kepentingan pribadi. Sedangkan Dimensi Instrinsik adalah suatu kecenderungan dimana agama menjadi motivasi dan kebutuhan hidup. Karenanya, secara sederhananya, dimensi

3 Susilo Wibisono, 2012. Orientasi Keberagamaan, Modal Sosial dan Prasangka terhadap Kelompok Agama Lain pada Mahasiswa Muslim. Jurnal Insan, Vol 14 No 3 Desember 2012 
ini bisa dibagi atas 3 (tiga) indikator meliputi; Agama untuk keselarasan hidup, agama untuk komitmen, dan agama sebagai sarana internalisasi ajaran dalam hidup.

Kemampuan berpikir kritis merupakan hal yang sangat penting dalam hidup. Berpikir kritis merupakan sebuah proses pembelajaran, dapat dikatakan bahwa berpikikir kritis lebih pada pengaruh lingkungan dan bukanlah permasalahan genetika. Untuk itulah, kemampuan ini harus ditumbuhkan dan tidak muncul dengan sendirinya. Halpern (1996) menyatakan bahwa berpikir kritis adalah pemberdayaan aspek kognitif dalam menentukan tujuan. Dengan demikian dapat dipahami bahwa kemampuan berpikir kritis berkembang sesuai dengan peningkatan kemampuan kognitifnya. Orang yang memiliki kemampuan kritis adalah mereka yang mau belajar dan tidak alergi terhadap kritik. Orang yang mampu berpikir kritis diasumsikan memiliki pribadi yang matang karena kemampuannya membatasi masalah sehingga tidak melebar dan mampu menyederhanakan suatu permasalahan. Disisi lain dapat disaumsikan sebagai orang yang terbuka terhadap perbedaan pendapat sehingga mampu memahami permasalahan dari berbagai sudut pandang yang berbeda. Lebih dari itu, orang yang berfikir kritis diidentikkan dengan teliti dan kemampuannya menggunakan data yang akurat. Hal ini demi menjaga akurasi data dan juga akurasi kesimpulan yang disusunnya.

Kemampuan berpikir kritis adalah suatu kemampuan yang ditumbuhkan, karenanya menjadi penting bagi seseorang untuk mempelajarinya dan sudah kewajiban seorang pendidik untuk bisa mengajarkannya. Untuk mengawalinya, bisa dengan membebaskan seorang untuk berkarya secara bebas ataupun mengeksplorasi dirinya. Untuk bisa mengukur tingkat daya kritis seseorang, dapat dilakukan dengan pemberian soal-soal tes pada level hots (higher order thinking skill) pada level atau tingkatakan kognitif menurut Bloom yang terbaru yakni pada level 4 (analisis), level 5 (evaluasi), dan level 6 yakni mencipta. Konsep taksonomi bloom lebih menfokuskan pada ingatan, pemahaman, penerapan, analisis, evaluasi dan juga mencipta yang kesemuanya itu bertujuan pada menyatukan seluruh perkembangan kemampuan seseorang dalam berpikir dan menguasai ilmu pengetahuan.

Metode pembelajaran juga dapat memotivasi seseorang untuk terbiasa berfikir kritis, salah satu metode pembelajaran yang dapat mengembangkan berfikir ktitis antara lain, problem Solving, yakni sintaks metode pembelajarannya lebih menfokuskan pada 
tujuan, sikap dalam menghadapi masalah, kata kunci permasalahan, informasi, sudut pandang, konsep, asumsi, alternatif pemecahan masalah, interpretasi dan implikasi. Kedua cara inilah yang apabila dikombinasikan akan mampu meningkatkan daya kritis seseorang. Berdasarkan analisis Moon bahwa berpikir kritis berpijak pada indikator sebagai berikut:1) Memiliki kemampuan secara jelas dan beralasan, 2)Membuktikan sesuatu disertai dengan bukti, 3) Memahami masalah dengan baik, 3) Menggunakan sumber yang terpercaya, 4) Mampu mempertimbangkan berbagai informasi untuk diolah, dianalisis dan disimpulkan

Ketiadaan daya berfikir kritis mengenai agama ditenggarai oleh persepsi bahwa ajaran agama tidak pernah salah. Kajian mengenai agama tidak dapat dilepaskan dari pembahasan unsur-unsur yang terkandung di dalam agama itu sendiri. Unsur-unsur tersebut meliputi doktrin, ritual, teks (nash), kepemimpinan (leadership), institusi, moralitas dan seni (art) ${ }^{4}$. Tujuh unsur agama inilah yang seringkali menjadi pemicu perselisihan keagamaan dikarenakan keyakinan para penganutnya bahwa semua unsur agama itu bersifat ta'abbudî (bertolak dari keyakinan) secara mutlak dan bahkan dinilai nonfalsifiable (tidak mungkin salah), sehingga menjadi incapable of being wounded; ghayr qâbil li al-niqâsy wa al-taghyîr atau anti kritik. Dalam memandang agama seharusnya dibedakan antara eksistensi Tuhan yang transenden dan institusi keagamaan serta pemikiran keagamaan yang memang merupakan hasil ciptaan manusia dan semestinya harus dikritisi secara cermat.

Penerapan sikap berfikir kritis terhadap agama ini berdasarkan kesadaran bahwa pemikiran manusia itu senantiasa mengalami perkembangan dan bersifat tentatif, sehingga tidak bisa terlepas dari kesalahan. Dalam mengkaji agama seharusnya bisa disandingkan aspek normativitas-sakralitas dengan aspek historisitas-profanitas agama, serta mengedepankan keterbukaan (openness) dan tidak berpikiran secara sempit (narrow-mindedness). Dengan keterbukaan, penggunaan pendekatan interkonektisitas atau multidimensionalitas dalam menelaah permasalahan keagamaan untuk menjadikan cakrawala pandang semakin meluas. Karenanya, dialog yang intens antara ilmu-ilmu

\footnotetext{
${ }^{4}$ Rodney Stark \& Charles Y Glock, Amrican Piety; The Nature of Religious Commitment, London: University of California Press, 1970
} 
keislaman dengan disiplin-disiplin keilmuan lain yang relevan semestinya senantiasa dijaga dan dilestarikan.

Berdasarkan dengan fenomena tersebut, peneliti tertarik untuk mengkaji lebih jauh akan pengaruh orientasi beragama terhadap kemampuan berpikir kritis pada mahasiswa Universitas Negeri Jakarta. Penelitian terkait dengan orientasi beragama sebagaimana yang dilakukan oleh Allport yang menegaskan bahwa mereka yang memiliki kecenderungan orientasi beragama yang ekstrinsik lebih intoleran dibanding mereka yang memiliki kecenderungan orientasi beragama yang intrinsik.

Peneliti membatasi permasalahan pada pengaruh orientasi pada daya kritis mahasiswa Universitas Negeri Jakarta sehingga bisa dirumuskan sebagai berikut, 'bagaimana orientasi beragama mahasiswa UNJ dan implikasinya pada daya pikir mahasiswa' sedangkan sub-rumusan adalah sebagai berikut: 1) Bagaimana kecenderungan orientasi beragama mahasiswa Universitas Negeri Jakarta?, 2) Bagaimana tingkat daya kritis mahasiswa Universitas Negeri Jakarta? 3) Hubungan orientasi beragama dengan daya kritis mahasiswa Universitas Negeri Jakarta?

\section{B. Metodologi Penelitian}

1. Pendekatan Penelitian

Pendekatan dalam penelitian ini adalah pendekatan mix method yakni menggunakan metode kuantitatif dan kualitatif dalam memetakan dan menganalisis kecenderungan orientasi beragama, kemampuan berpikir kritis serta keterkaitan antara kedua variabel tersebut.

2. Responden Penelitian

Populasi responden dalam penelitian ini adalah mahasiswa Universitas Negeri Jakarta. Sampel yang digunakan mahasiswa Universitas Negeri Jakarta yang mengambil Mata kuliah Umum Pendidikan Agama Islam.

\section{Intrumen Penelitian}

Instrumen Penelitian yang digunakan untuk pendekatan mix method deskriptif analisis dengan kuesioner untuk mengetahui arah orientasi beragama responden dan diperkuat dengan dan wawancara guna menggali lebih dalam akan alasan atau kemengapaan pada variabel orientasi beragama dan juga kemampuan daya pikir. 
Penelitian ini dilengkapi pula dengan observasi dan pengamatan atas responden penelitian

4. Analisis Data

Analisis data menggunakan SPSS edisi 22, khususnya dengan menggunakan analisis produk moment untuk mendeskripsikan hubungan antara variebal orientasi beragama dan kemampuan berpikir kritis. Juga menggunakan uji-t untuk melihat perbedaan demografis terkait variabel, baik itu variebal orientasi beragama dan variabel kemampuan berpikir kritis

\section{Hasil dan Pembahasan}

Responden penelitian ini adalah 91 mahasiswa MKU yang mengambil mata kuliah Pendidikan Agama Islam. Dari data kuesioner yang dibagikan, di dapat data sebagai berikut,

\section{Orientasi Beragama Mahasiswa UNJ}

Untuk melihat tinggi rendahnya orientasi beragama, maka dibuatkah interpretasi skor sebagai berikut:

Tabel 1. Pedoman Interpretasi Skor

\begin{tabular}{cc}
\hline Kategori & Norma \\
\hline Tinggi & $X \geq$ Mean \\
Rendah & $X<$ Mean \\
\hline
\end{tabular}

Sumber: Hasil Penelitian

Secara garis besar gambaran tinggi rendahnya orientasi beragama mahasiswa responden adalah sebagai berikut:

Tabel 2. Tingkat Orientasi Beragama

\begin{tabular}{|l|c|c|c|c|}
\hline & \multicolumn{2}{|c|}{ Tinggi } & \multicolumn{2}{c|}{ Rendah } \\
\hline Orientasi Beragama & 56 & $53 \%$ & 35 & $47 \%$ \\
\hline Orientasi Ekstrinsik & 53 & $58 \%$ & 38 & $42 \%$ \\
\hline Orientasi Instrinsik & 48 & $55 \%$ & 43 & $45 \%$ \\
\hline
\end{tabular}

\section{Sumber: Hasil Penelitian}

Data diatas menunjukkan bahwa orientasi beragama responden cukup berimbang antara yang memiliki tingkat tinggi dan juga rendah, karena umunya berkisar diatas $40 \%$. Dari data tersebut tampak jelas bahwa orientasi beragama mahasiswa masih didominasi oleh orientasi ekstrinsik dimana agama digunakan untuk memperoleh keamanan, 
mengatasi kebingungan, serta memperjelas status. Agama disesuaikan dengan kepentingan pribadi. Untuk melihat lebih jelas akan perbedaan orientasi beragama responden dilihat dari data demografinya, dijelaskan dalam banyak tabel sebagai berikut,

Keberimbangan antara tingkat tinggi dan rendah pun bisa dipahami dari bagaimana responden terkadang tidak begitu yakin dengan jawaban yang mereka berikan. Dari observasi kelas tampak bahwa responden berupaya untuk menghayati agama walau di lain sisi, mereka pun menjadikan sisi keberagamaannya sebagai penegasan atas statusnya.

Tabel 3. Perbedaan Jenis Kelamin

\begin{tabular}{|l|l|c|c|c|c|c|}
\hline \multicolumn{2}{|c|}{} & \multicolumn{2}{|c|}{$\begin{array}{c}\text { Levene's Test for } \\
\text { Equality of } \\
\text { Variance }\end{array}$} & \multicolumn{2}{|c|}{ t-test for equality of meas } \\
\cline { 3 - 7 } & $\mathrm{F}$ & Sig & $\mathrm{T}$ & Df & Sig. (2-Tailed) \\
\hline Orientasi Beragama & $\begin{array}{l}\text { Equal } \\
\text { variances } \\
\text { assumed }\end{array}$ & 3.609 & .061 & -3.392 & 89 & .001 \\
\hline Orientasi Ekstrinsik & $\begin{array}{l}\text { Equal } \\
\text { variances } \\
\text { assumed }\end{array}$ & 8.040 & .006 & -2.944 & 89 & .004 \\
\hline Orientasi Instrinsik & $\begin{array}{l}\text { Equal } \\
\text { variances } \\
\text { assumed }\end{array}$ & .843 & .361 & -4.236 & 89 & .000 \\
\hline
\end{tabular}

Sumber: Hasil Penelitian

Dari data diatas tampak bahwa output t-test diperoleh nilai Sig.(2-tailed) sebesar $0.001,0.004$ dan 0.000 dimana ketiganya < 0.05, maka sesuai dasar pengambilan keputusan dalam uji independent sample t-tes dapat disimpulkan bahwa akan adanya perbedaan antara responden laki-laki dan perempuan dalam Orientasi beragama, baik itu secara umum maupun secara spesifik, yakni orientasi ekstrinsik maupun instrinsiknya.

Hasil penelitian ini seolah sejalan dengan penelitian Pew research center yang menghasilkan temuan bahwa tingkat religiusitas wanita lebih tinggi dibandingkan pria. ${ }^{5}$ Walau penelitian tersebut lebih mencermati tingkat religiusitas wanita non-muslim yang ditunjukkan melalui tingkat kehadirannya dalam ruang ibadah publik, namun bukan berarti tingkat religiusitas wanita muslim lebih rendah. Kehadiran Pria muslim di ruang ibadah publik lebih didorong dan disukai dibandingkan kehadiran Muslimah atau wanita muslim yang justru lebih dianjurkan untuk beribadah di ruang privat, sehingga tidak mudah terekspos.

5 Lihat lebih lanjut di http://www.pewforum.org/religious-landscape-study/gendercomposition/women/ 
Tabel 4. Perbedaan Keaktifan dalam Pengajian dan Pengkajian

\begin{tabular}{|l|lc|c|c|c|c|c|}
\hline \multicolumn{2}{|l|}{} & \multicolumn{2}{|c|}{$\begin{array}{l}\text { Levene's Test } \\
\text { for Equality of } \\
\text { Variance }\end{array}$} & \multicolumn{2}{|c|}{ t-test for equality of meas } \\
\cline { 4 - 8 } & & $\mathrm{F}$ & Sig & $\mathrm{T}$ & Df & $\begin{array}{c}\text { Sig. } \\
(2- \\
\text { Tailed } \\
)\end{array}$ \\
\hline Orientasi Beragama & $\begin{array}{l}\text { Equal } \\
\text { assumed }\end{array}$ & variances & .502 & .480 & -1.930 & 89 & .131 \\
\hline Orientasi Ekstrinsik & $\begin{array}{l}\text { Equal } \\
\text { assumed }\end{array}$ & variances & .750 & .389 & -1.468 & 89 & .146 \\
\hline Orientasi Instrinsik & $\begin{array}{l}\text { Equal } \\
\text { assumed }\end{array}$ & variances & 8.470 & .005 & -1.525 & 89 & .057 \\
\hline
\end{tabular}

Sumber: Hasil Penelitian

Dari data diatas tampak bahwa output t-test diperoleh nilai Sig.(2-tailed) sebesar $0.131,0.146$ dan 0.057. Sesuai dasar pengambilan keputusan dalam uji independent sample t-tes, bila nilai sig. (2-tailed) $>0.05$ dapat disimpulkan akan tidak terdapat perbedaan dan bila nilai sig. (2-tailed) $<0.05$ dapat disimpulkan akan adanya perbedaan. Dengan demikian, maka dinyatakan tidak ada perbedaan antara responden yang aktif mengikuti pengajian dan pengkajian dalam orientasi beragama secara umum, ataupun dalam orientasi ekstrinsiknya. Namun demikian, ditemukan perbedaan antara mereka yang aktif mengikuti pengajian dan pengkajian dalam orientasi instrinsiknya.

Dengan demikian, seolah bisa disimpulkan sementara bahwa pengajian dan pengkajian dapat meningkatkan orientasi instrinsik pada seseorang. Hal ini berlaku dikarenakan pengajian dan pengkajian lebih menekankan pada pemenuhan spiritualitas dan mengembangkan motivasi dalam diri untuk bisa berbuat lebih baik. Agama seyogyanya menjadi pedoman hidup bagi pemeluknya untuk menjadi lebih baik. Selain itu, mengenal diri sendiri lebih baik pun merupakan jalan untuk bisa mengenal Tuhan. Hal tersebut menegaskan bahwa beragama lebih baik terjadi melalui proses dalam diri.

\section{Daya Kritis Mahasiswa UNJ}

Untuk melihat tinggi rendahnya daya kritis mahasiswa, maka dibuatkah interpretasi skor sebagai berikut.

Tabel 5. Pedoman Interpretasi Skor

\begin{tabular}{cc}
\hline Kategori & Norma \\
\hline Tinggi & $X \geq$ Mean \\
Rendah & $X<$ Mean \\
\hline
\end{tabular}

Sumber: Hasil Penelitian 
Tabel 6. Tingkat Daya Kritis Mahasiswa

\begin{tabular}{|l|c|c|c|c|}
\hline & \multicolumn{2}{|c|}{ Tinggi } & \multicolumn{2}{c|}{ Rendah } \\
\hline Daya Kritis & 45 & $49 \%$ & 46 & $51 \%$ \\
\hline
\end{tabular}

Sumber: Hasil Penelitian

Bila dilihat, perbedaan mereka yang memiliki daya kritis yang tinggi tidak jauh berbeda dengan mereka yang memiliki daya kritis yang rendah, walaupun terlihat bahwa mereka yang memiliki daya kritis rendah lebih banyak. Hal ini dikarenakan daya kritis yang dimaksud lebih pada daya kritis dalam beragama. Dari beberapa wawancara, terdapat kekhawatiran dalam diri responden untuk bersikap kritis atas ajaran agama, karena mereka memahaminya sebagai satu dogma yang tidak bisa dipertanyakan; walau sebagian lainnya tetap mencoba menggunakan nalarnya untuk memahami ajaran agama.

Untuk bisa memahami daya kritis dalam beragama responden lebih jauh, ada baiknya melihat data angket sebagai berikut:

Tabel 7. Instrument Pertanyaan

\begin{tabular}{|l|c|c|c|c|}
\hline \multicolumn{1}{|c|}{ Pernyataan } & $\mathbf{1}$ & $\mathbf{2}$ & $\mathbf{3}$ & $\mathbf{4}$ \\
\hline $\begin{array}{l}\text { Dikala saya menemukan pemahaman agama yang bersebrangan, saya siap } \\
\text { untuk mempertanyakan }\end{array}$ & 1 & 23 & 33 & 32 \\
\hline $\begin{array}{l}\text { Dikala saya menemukan pemahaman agama yang membingungkan, saya } \\
\text { akan mengkaji lebih jauh dengan merujuk kepada sumber yang bisa } \\
\text { dipercaya }\end{array}$ & 2 & 31 & 32 & 26 \\
\hline $\begin{array}{l}\text { Disaat saya melihat pemahaman agama yang tampak menyesatkan, saya } \\
\text { akan menganalisisnya dengan pengetahuan agama yang saya miliki }\end{array}$ & 7 & 35 & 35 & 14 \\
\hline
\end{tabular}

\section{Sumber: Hasil Penelitian}

Dari data diatas tampak berimbang antara mereka yang berupaya berpikir kritis dalam memahami ajaran agama dengan mereka yang belum dan tidak mengasah kemampuan berpikir kritisnya dalam beragama karena satu dan lain halnya. Menariknya, dalam observasi kelas, responden yang merasa bahwa dirinya belum cukup kritis, mengungkapkan bahwa dalam beragama, cukup baginya untuk mengikuti perkataan ustadz atau ustadzahnya. Ada kekhawatiran dalam dirinyab bila ia kritis, maka akan terseret dalam dunia sekuler dan seolah mempertanyakan ajaran yang di terima.

Untuk melihat lebih jelas akan perbedaan daya pikir dalam beragama beragama responden dilihat dari data demografinya, dijelaskan dalam banyak tabel sebagai berikut: 
Tabel 8. Perbedaan Jenis Kelamin

\begin{tabular}{|c|c|c|c|c|c|c|}
\hline & \multicolumn{2}{|c|}{$\begin{array}{c}\text { Levene's Test } \\
\text { for Equality of } \\
\text { Variance }\end{array}$} & \multicolumn{3}{|c|}{ t-test for equality of meas } \\
\hline & & $\mathrm{F}$ & Sig & $\mathrm{T}$ & Df & $\begin{array}{l}\text { Sig. }(2- \\
\text { Tailed) }\end{array}$ \\
\hline Daya Kritis & $\begin{array}{ll}\text { Equal } & \text { variances } \\
\text { assumed } & \\
\end{array}$ & .452 & .503 & 1.965 & 89 & .053 \\
\hline
\end{tabular}

Sumber: Hasil Penelitian

Dari data diatas tampak bahwa output t-test diperoleh nilai Sig.(2-tailed) sebesar $0.053<0.05$, maka sesuai dasar pengambilan keputusan dalam uji independent sample ttes dapat disimpulkan akan adanya perbedaan antara responden laki-laki dan perempuan dalam kemampuan berpikir kritis dalam beragama. Hal ini tampak jelas bahwa umumnya laki-laki lebih kritis dalam bertindak di berbagai hal, termasuk dalam beragama dibandingkan perempuan yang terkesan menerima arahan apa adanya.

Tabel 9. Perbedaan Keyakinan akan Daya Berfikir Kritis

\begin{tabular}{|l|l|c|c|c|c|c|}
\hline \multicolumn{2}{|c|}{} & \multicolumn{3}{|c|}{$\begin{array}{c}\text { Levene's Test for } \\
\text { Equality of Variance }\end{array}$} & \multicolumn{2}{|c|}{ t-test for equality of meas } \\
\cline { 3 - 7 } & $\mathrm{F}$ & Sig & $\mathrm{T}$ & Df & $\begin{array}{c}\text { Sig. (2- } \\
\text { Tailed) }\end{array}$ \\
\hline Daya Kritis & $\begin{array}{l}\text { Equal variances } \\
\text { assumed }\end{array}$ & .018 & .893 & -2.187 & 89 & 0.031 \\
\hline
\end{tabular}

Sumber: Hasil Penelitian

Dari data diatas tampak bahwa output t-test diperoleh nilai Sig.(2-tailed) sebesar $0.031<0.05$, maka sesuai dasar pengambilan keputusan dalam uji independent sample ttes dapat disimpulkan bahwa terdapat perbedaan antara responden yang memiliki keyakinan akan kekritisan dirinya dengan yang tidak dalam tingkat kemampuan berpikir kritisnya. Dengan demikian bisa disimpulkan bahwa keyakinan akan diri sendiri mampu mengarahkan pada perilaku yang sesungguhnya.

Hal ini diperkuat dengan teori bahwa afirmasi diri menjadikan seseorang semakin percaya diri untuk bisa membuktikan kemampuannya. Karenanya, seseorang yang dengan yakin bahwa dirinya bisa melakukan sesuatu, maka akan lebih mudah baginya menjalankan dibandingkan mereka yang minder dan apatis dengan kemampuan dirinya sendiri.

\section{Hubungan Orientasi Beragama dan Daya Kritis Mahasiswa UNJ}

Dengan menggunakan SPSS, didapatkan hubungan orientasi beragama terhadap daya kritis mahasiswa UNJ sebagai berikut, 
Tabel 10. Correlations

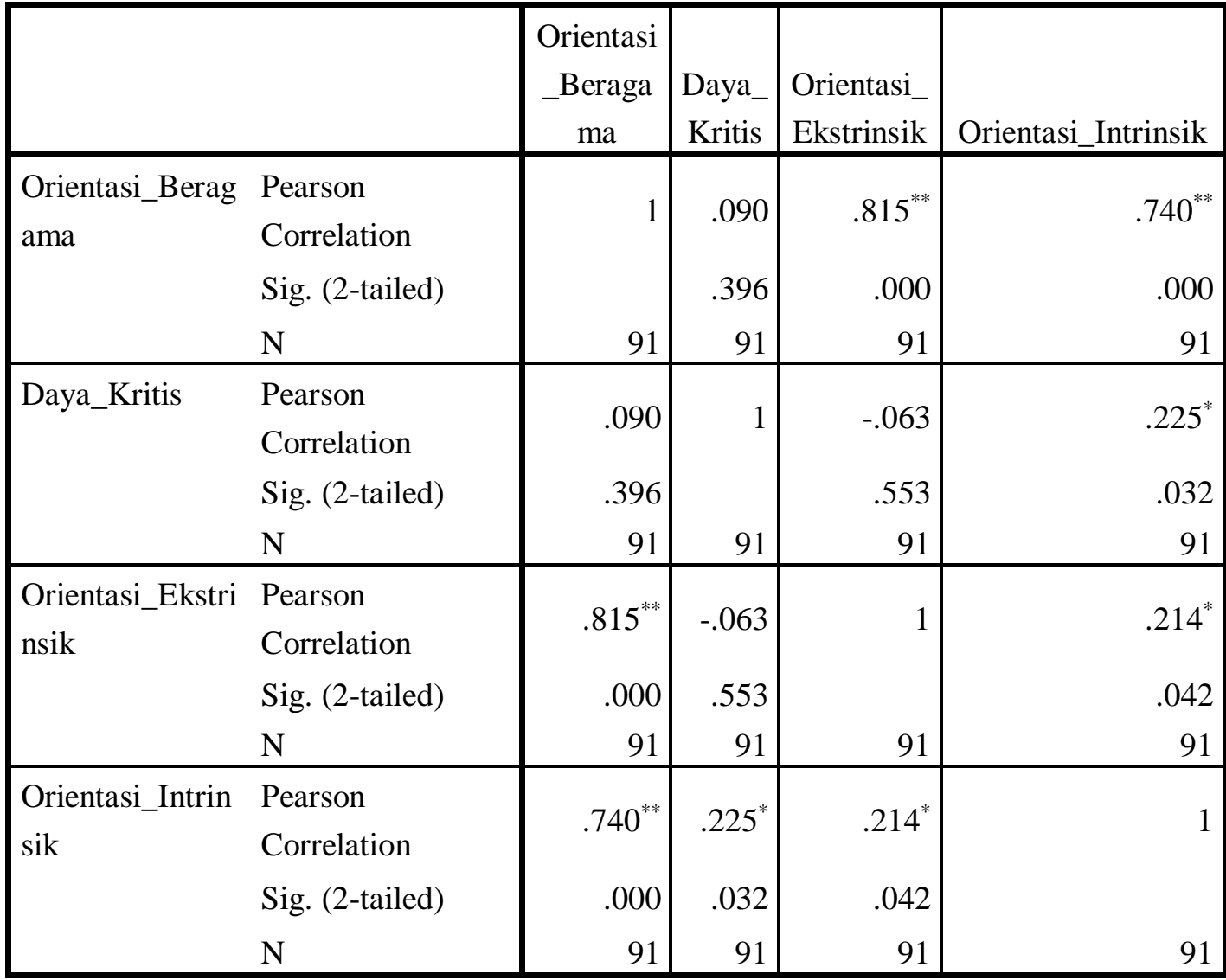

**. Correlation is significant at the 0.01 level (2-tailed).

*. Correlation is significant at the 0.05 level (2-tailed).

Data di atas menunjukkan bahwa orientasi beragama tidak berhubungan langsung dengan daya kritis. Namun saat data tersebut dipecah menjadi data orientasi instrinsik dan orientasi ekstrinsik, maka tampak jelas bahwa hubungan antara orientasi instrinsik dalam beragama dengan daya kritis. Untuk lebih memperjelas dan mempertegas seberapa kuat hubungan dan pengaruh, peneliti kembali menguji data yang ada menggunakan regresi dengan metode backward. Metode ini dilakukan dengan memasukkan semua prediktor untuk kemudian mengeliminasi satu persatu hingga tersisa prediktor yang signifikan saja.

Dengan menggunakan data backward, didapatkan kesimpulan bahwa variabel yang mempengaruhi hasil dari pengaruh dan harus dikeluarkan adalah orientasi ekstrinsik. Dengan demikian, maka jelaslah bahwa yang memiliki pengaruh dengan daya kritis adalah orientasi instrinsik. Namun seberapa besar pengaruhnya, bisa dilihat dengan data sebagai berikut: 
Tabel 3.3. Model Summary

\begin{tabular}{|c|c|c|c|c|}
\hline Model & $\mathrm{R}$ & R Square & Adjusted R Square & $\begin{array}{l}\text { Std. Error of the } \\
\text { Estimate }\end{array}$ \\
\hline 1 & $.252^{\mathrm{a}}$ & .063 & .042 & 1.788 \\
\hline 2 & $.225^{\mathrm{b}}$ & .051 & .040 & 1.790 \\
\hline
\end{tabular}

a. Predictors: (Constant), Orientasi_Intrinsik, Orientasi_Ekstrinsik

b. Predictors: (Constant), Orientasi_Intrinsik

Data menunjukkan bahwa pengaruh orientasi instrinsik terhadap daya pikir mencapai 5,1\%. Walau terkesan sangat sedikit, dimana 94,9\% lainnya dipengaruhi oleh faktor lain, namun cukup menarik.

Ketiadaan korelasi antara orientasi beragama dan daya pikir bisa disebabkan banyak faktor. Salah satunya adalah keraguan responden dalam mengidentifikasi dirinya sebagai seseorang yang termasuk tingkatan yang memiliki kritis dalam beragama ataukah hanya sebagai pengikut dalam beragama yang bersifat dogmatis.

Hal ini seolah bertentangan dengan pepatah Arab, yang diyakini sebagai hadis Nabi Muhammad, yang berbunyi, al-dinu huwa al-aql, agama adalah akal; atau dipahami bahwa keberagamaan seseorang selaras dengan daya pikir. Akal atau nalar adalah substansi agama; dan merupakan salah satu unsur penting di dalam agama. Hal tersebut meneguhkan bahwa agama bukan sekadar wacana, namun juga merupakan menggambarkan sejarah perkembangan rasio atau nalar itu sendiri.

Lemahnya daya pikir dan nalar dalam beragama akan menutup akses kepada kesadaran bahwa ada ayat-ayat suci agama yang ditulis ribuan tahun lalu tidak bisa diterapkan secara literer dalam konteks sebuah kondisi yang berbeda secara konteks. Ayat-ayat suci ini perlu diinterpretasi secara kritis, dan itu adalah tugas nalar.

Namun bila merujuk kepada responden yang umumya ragu dan takut untuk bisa bersikap kritis, maka orientasi keberagamaannya berjalan tanpa beriringan dengan daya pikirnya sehingga dengan demikian, hasil penelitian yang ada bisa dimaklumi adanya. Karenanya dibutuhkan penguatan dan pengkajian agar mahasiswa mampu menggunakan daya nalarnya hingga mampu beragama secara optimal 


\section{Penutup}

\section{Kesimpulan}

Berdasarkan hasil penelitian bisa disimpulkan bahwa Orientasi beragama mahasiswa belum sejalan dan selaras dengan daya pikir nalarnya. Ada sedikit harapan dikala ditemukan bahwa orientasi instrinsik ternyata cukup mampu memberikan pengaruh kepada daya pikir hingga dengan demikian dibutuhkan penguatan lebih baik lagi dalam upaya meningkatkan orientasi beragama instrinsik mahasiswa melalui banyak kegiatan, salah satunya melalui penguatan wawasan dan kajian keagamaan.

\section{Saran}

Berdasarkan kesimpulan yang dibuat, maka disusunlah saran sebagai berikut:

a) Agar angket yang ada diujicobakan kepada mahasiswa yang lebih mapan dan mampu mengidentifikasi dirinya dengan baik, sehingga hasil yang didapat pun menjadi lebih jelas.

b) Berdasarkan data penelitian, maka untuk meningkatkan orientasi intrinsik seseorang, bisa dilakukan dengan mengarahkannya untuk mengikuti pengajian dan pengkajian

\section{E. Daftar Pustaka}

Allport, G. W. \& Michael J. R. 1967. Personal religious orientation and prejudice. Journal of Personality and Social Psychology 5(4):432-43.

Alkind, David dan John H Flavell, 1969. Studies in Cognitive development; essays in honor of Jean Piaget. New York: Oxford University Press

Barret, D.W, Peckham, J.A.P, Hutchinson, G.T \& Nagoshi, C.T. 2004. Cognitive motivation and religious orientation. Personality and Individual Differences 38 (2005) 461-474

Din Syamsuddin, 1997. Peta keberagamaan Indonesia, Jakarta: UIN Press

Halpern, DF, 1996. Thinking Critically About Critical Thinking: An Exercise Book to Accompany Thought and Knowledge: An Introduction to Critical Thinking (3 ${ }^{\text {rd }}$ ed). Mahwah, NJ: Lawrence Erlbaum Associates, Inc. Publishers 2014. Thought and Knowledge: An Introduction to Critical Thinking (5 $5^{\text {th }}$ ed). NY: Psychology Press 
Moon, Jennifer, 2008. Critical Thingking (An Exploration of Theory and Practice). New York: Routledge.

Rakhmat, Jalaluddin, 2004. Psikologi Agama; sebuah pengantar. Jakarta: Mizan

Sternberg, R., Roediger, R \& Halpern, DF (Eds), 2007. Critical Thinking in Psychology. Cambridge. MA: Cambridge University Press.

Stark, Rodney \& Charles Y Glock, 1970. Amrican Piety; The Nature of Religious Commitment. London: University of California Press

Susilo Wibisono, 2012. Orientasi Keberagamaan, Modal Sosial dan Prasangka terhadap Kelompok Agama Lain pada Mahasiswa Muslim. Jurnal Insan, Vol 14 No 3 Desember 2012

Thouless, RH, 1992. Pengantar Psikologi Agama, terj. Machnun Husein. Jakarta: Rajawalipress

Tumanggor, Rusmin, 2014. Ilmu Jiwa Agama. Jakarta: Kencana 
